Anastomose, nach heutigem Wissen allerdings die günstigste, da sie das Gallenwegssystem am tiefsten Punkt drainiert. Wir führen in der Regel die endoskopische Sphincterotomie bei Fällen von Choledocholithiasis bei Zustand nach Cholecystektomie durch, wenn der Patient älter als 60 Jahre ist oder ein entsprechend erhöhtes Operationsrisiko besteht.

Schliisselwörter: Choledocholithiasis - Endoskopische Sphincterotomie.

\title{
266. Fehler und Gefahren der chirurgischen und endoskopischen Papillotomie
}

\author{
P. Gerometta, K. H. Schriefers, E. Seifert, Y. Gök und J. Weismüller \\ Chirurgische und I. Medizinische Klinik am Städt. Krankenhaus „Kemperhof“", \\ Koblenzer Straße 115, D-5400 Koblenz
}

\section{Failures and Dangers of Surgical and Endoscopic Papillotomy}

Summary. A total of 393 endoscopic papillotomies (mortality $3.3 \%$, complication rate $8.9 \%$ ) are compared with 672 operations of the choledochus of which 342 were transduodenal papillotomies (with a mortality of $3.2 \%$ and a complication rate of $9.1 \%$ ) and 330 cholangiotomies (with a mortality of $2.1 \%$ ). Dangerous complications that occurred after the operation were pancreatitis and purulent or bilious abscesses. Retroduodenal leakages, massive haemorrhages and septic cholangitis often resulted from endoscopic papillotomy and 22 patients needed urgent laparotomy. The mortality of these operations was $36 \%$ and was mostly due to septic conditions. Key words: Transduodenal papillotomy - Endoscopic papillotomy - Septic cholangitis - Retroduodenal leakage.

Zusammenfassung. 393 endoskopische Papillotomien (Letalität 3,3\%, Komplikationsrate 8,9\%) werden 672 Gallengangsoperationen gegenübergestellt, davon 342 transduodenale Papillotomien (Letalität 3,2\%, Komplikationen $9,1 \%$ ) und 330 Cholangiotomien (Letalität 2,1\%). Häufigste postoperative Komplikationen waren Pankreatitiden und Oberbauchabscesse, nach der endoskopischen Papillotomie stehen retroduodenale Leckbildungen, massive Blutungen und septische Cholangitiden im Vordergrund. 22 endoskopisch papillotomierte Patienten mußten notfallmäßig laparotomiert werden, die Letalität dieser Eingriffe von $36 \%$ geht vorwiegend zu Lasten septischer Krankheitsbilder.

Schlüsselwörter: Transduodenale Papillotomie - Endoskopische Papillotomie - Septische Cholangitis Retroduodenale Leckbildung.

\section{Maligner Verschlußikterus - endoskopische transpapilläre biliäre Drainage}

\author{
N. Soehendra, K. de Heer und I. Kempeneers
}

Abteilung für Allgemeinchirurgie der Chirurgischen Universitäts-Klinik, Hamburg-Eppendorf, Martinistraße 52, D-2000 Hamburg

\section{Malignant Obstructive Jaundice - Endoscopic Transpapillary Drainage}

\begin{abstract}
Summary. Endoscopic transpapillary drainage with the "pig tail" endoprosthesis is a suitable method for palliative decompression in patients with inoperable obstructions of the bile duct. The procedure has a success rate of $80 \%$ and a lower risk rate than the percutaneous transhepatic method. Complications occur in about $15 \%$ of patients with a mortality of $2.8 \%$. The internal drainage does not have the disadvantage of the bile-loss syndrome. If the prosthesis becomes blocked, it can be changed without difficulty. Where cholangitis occurs, a nasobiliary tube can also be introduced in addition.
\end{abstract}

Key words: Endoscopic biliary endoprosthesis.

Zusammenfassung. Die endoskopische transpapilläre Drainage mit der „Pigtail“ Endoprothese eignet sich zur palliativen Dekompression bei Patienten mit inoperablen Gallengangverschlüssen. Das Verfahren ist in $80 \%$ erfolgreich und hat ein niedrigeres Risiko als die percutan-transhepatische Methode. Komplikationen treten in 